\title{
Characteristics of environmental harm in the context of air pollution
}

\author{
J. G. Irwin, R. Duarte-Davidson \& S. J. T. Pollard \\ National Centre for Risk Analysis and Options Appraisal, Environment \\ Agency, United Kingdom.
}

\begin{abstract}
A framework that allows a simple qualitative assessment of both technical and socio-economic aspects of environmental harm has been developed; that is a framework that captures not only the physical aspects of damage but also how society may feel about it. Technical characteristics of harm include spatial and temporal extent, severity, irreversibility and uniqueness. Social aspects include dread, distrust, equity and imposition. By plotting these on separate axes of a graph it is possible to assess those attributes of greatest concern, draw conclusions as to the nature of the harm, and public perception of it, as well as gaining some insight into appropriate courses of action. The results of applying the methodology to a radioactive release are presented and placed in the context of a range of other air pollution hazards.
\end{abstract}

\section{Introduction}

Comparing the environmental harm arising from a range of hazards to different receptors is difficult. Conventionally harm to the environment is assessed by the magnitude of the impact, usually by reference to the exceedence, or otherwise, of environmental standards. However, the use of standards in isolation has limitations. They may not take into account other important characteristics of the damage such as delayed onset, irreversibility or the uniqueness of the environmental resource at risk. Nor do they necessarily take account of the values society places on different components of the environment. These broader aspects are critical to strategic decision-making and become particularly important when prioritising issues. The approach described here involves identifying technical and 


\section{Air Pollution X}

social characteristics of environmental harm (e.g. severity, reversibility, spatial and temporal extent, latency, dread, equity) using key words, or 'attributes'. These are then scored on a simple qualitative scale and displayed graphically.

\section{Environmental standards}

The adoption of standards has served regulators well in so far as it has provided clarity for the regulated community as to what levels are considered acceptable in different environmental media. However, their derivation and adoption are surrounded by difficulties, as highlighted by the Royal Commission on Environmental Pollution [1].

The use of standards to act as surrogates for environmental harm has, arguably, led to an implicit assumption that any exceedence of the standard will result in detriment. This is not necessarily the case as the derivation of the standard involves 'safety margins' in the form of uncertainty factors that act in a precautionary fashion. In addition, if a standard is to be achieved in practice, it is important to take account of the cost of attaining the standard as well as the significance of the harm and the opportunities for reducing it. Two particular situations illustrate the limitations of a standard-based approach:

(i) Managing harm from low probability, high consequence events often requires an understanding of the characteristics of harm beyond its potential magnitude so that good contingency measures can be set in place, should the consequences be realised.

(ii) At a strategic level, the comparison of risks is problematic because there is no accepted way of comparing the harm arising from say, flood damage with that from the contamination of soils, or from stratospheric ozone depletion with harm to an important aquifer. A purely technical approach often proves too restrictive, and monetisation, in isolation, fails to capture aspects of harm beyond an estimate of the 'stock at risk'. These difficulties are often encountered when attempting to prioritise disparate risks.

\section{Attributes of harm}

In estimating the risks inherent in global change the German Advisory Council on Global Change (WGBU) have developed a qualitative classification of global risks to assist identification of preferred management strategies. The approach considers both the probability of damage occurring and the certainty in that assessment. In doing so they have considered wider aspects of harm by having an attribute to take account of social values. Key attributes considered were extent (and certainty in the assessment of extent), reversibility, persistence, ubiquity, latency; and also social and political mobilisation arising from severe conflict and dread in the general population [2].

The approach described here draws on the WBGU work and involves capturing the characteristics of environmental harm (magnitude, reversibility, spatial and temporal extent, latency etc.) using key words, or 'attributes', with 
meaning in a technical and socio-economic context. Candidate interpretations from the literature were reviewed and an initial set of attributes was developed and tested. The attributes were then reassessed and a consensus reached on a core set $[3,4]$. These attributes were further refined using the Environment Agency's State of the Environment Report [5] as a case study for prioritising issues at a strategic level.

The core set of attributes is presented in Tables 1 and 2. For each attribute a short description and examples are shown. The list of attributes has been divided into those that 'objectively' describe the nature of the harm (what we know about the harm; Table 1) and those that describe 'subjective' stakeholder reactions to it (i.e. how we feel about the harm; Table 2). Interestingly, this latter group can be sub-divided into two sets, one relating to personal concern - dread, unfamiliarity and the other taking account of discontent - equity, imposition and distrust. Scales have been developed for each attribute [4] using a simple qualitative approach (low, medium and high). Greater understanding of both the approach and the interactions between attributes would be required before any weighting system could be adopted. The attributes may be grouped and displayed graphically. Attributes that have been plotted it the shaded area of Figure 1 will cause the highest overall impact in terms of the nature of the harm and/or our response to it.

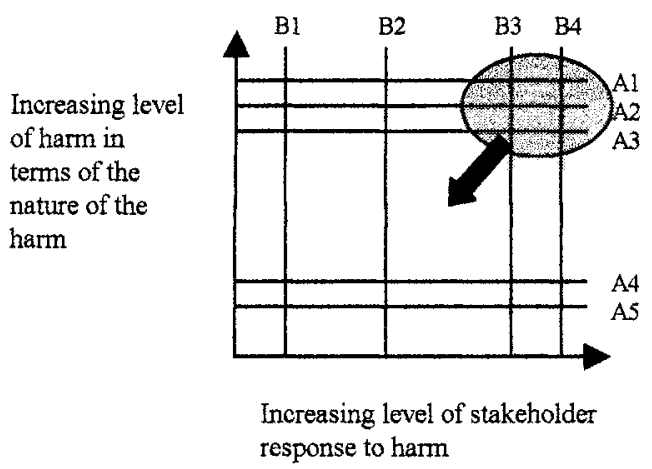

Figure 1: Graphical representation of attributes

\section{Application to air pollution issues}

The approach was applied to a number of major risks to the atmospheric environment identified in the Environment 2000 and Beyond Report [5]. In order to ensure that any preconceived bias did not skew the scoring, the exercise was carried out in a workshop setting with a facilitator and a group consisting of experts in both technical aspects of air pollution and social issues. In each case Environment Agency staff provided a briefing on technical aspects of the issues considered, which were: 


\section{Air Pollution X}

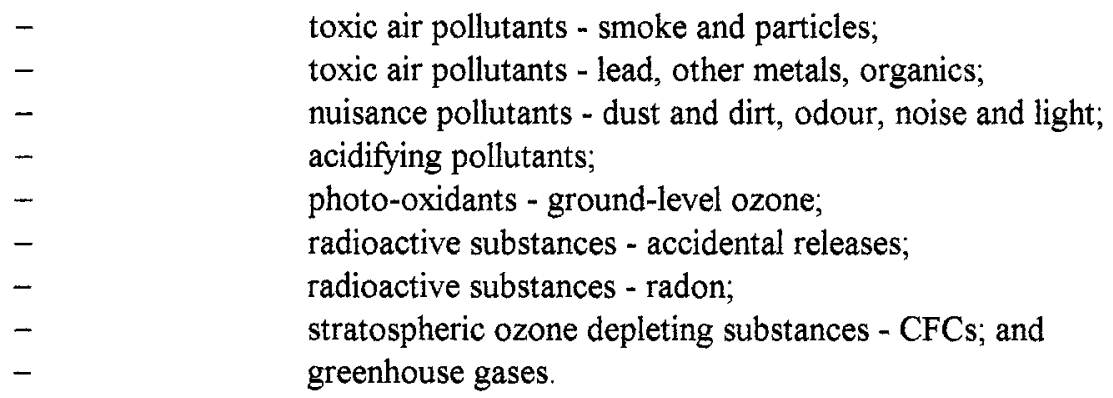

The results of applying this approach to an accidental release to atmosphere of a radioactive substance are illustrated in Figure 2.

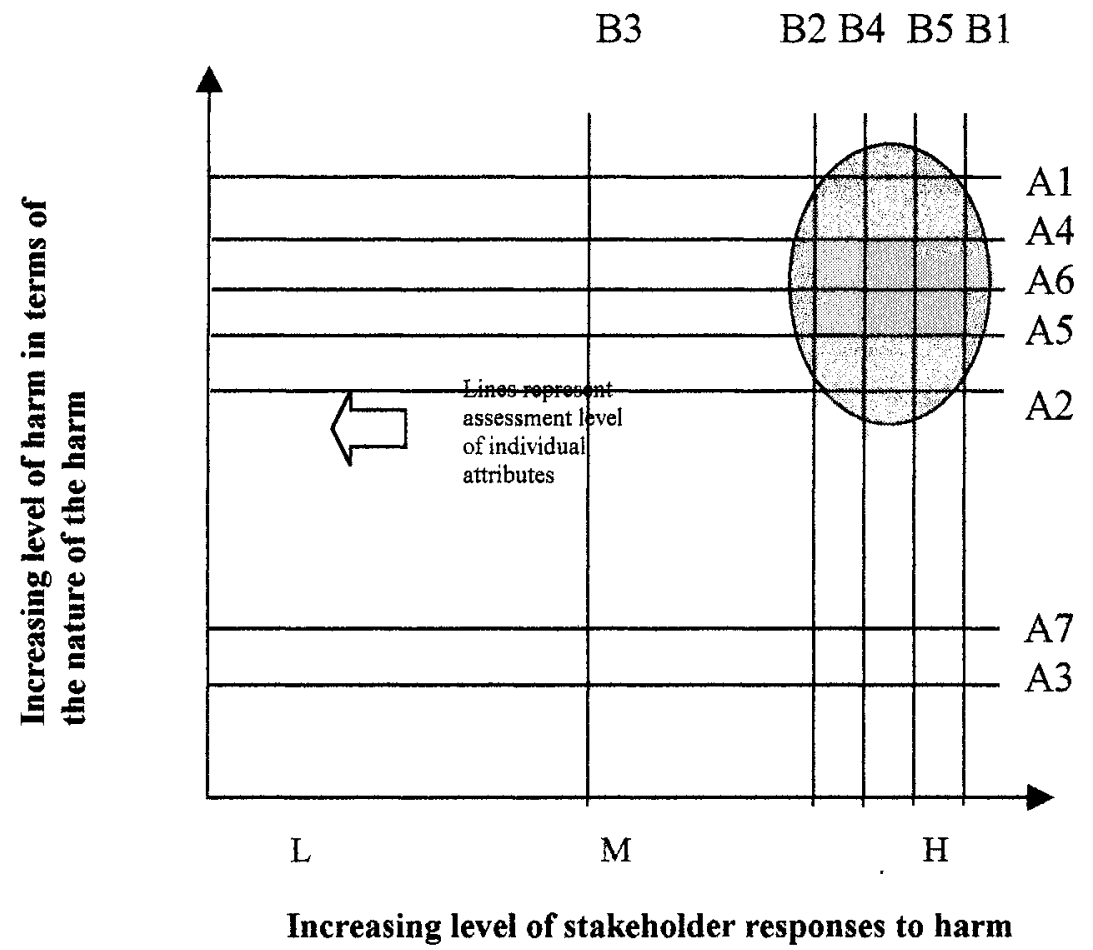

Figure 2: Illustrative attribute scores for an accidental release of radioactive gases. 
Table 1. Examples of Physical Harm Attributes

\begin{tabular}{|c|c|c|}
\hline $\begin{array}{l}\text { Harm } \\
\text { Attribute }\end{array}$ & Description & Examples \\
\hline $\begin{array}{l}\text { Al } \\
\text { Stock at risk }\end{array}$ & $\begin{array}{l}\text { This term refers to how } \\
\text { many people might be } \\
\text { affected/how much of } \\
\text { a particular } \\
\text { environment might be } \\
\text { damaged/lost }\end{array}$ & $\begin{array}{l}\text { Number of people affected / value of the stock (in } \\
\text { financial terms). }\end{array}$ \\
\hline $\begin{array}{l}\text { A2 } \\
\text { Spatial extent }\end{array}$ & $\begin{array}{l}\text { Distribution of harm in } \\
\text { geographical space }\end{array}$ & $\begin{array}{l}\text { Harm may affect a localised area (e.g. siting of an } \\
\text { industrial plant, incinerator or landfill site close to a } \\
\text { housing estate or valuable ecological site) or could } \\
\text { hrve widespread implications (e.g. global harm } \\
\text { such as effects from climate change). }\end{array}$ \\
\hline $\begin{array}{l}\text { A3 } \\
\text { Heterogeneity }\end{array}$ & $\begin{array}{l}\text { Distribution of harm } \\
\text { manifest. Some } \\
\text { impacts may affect a } \\
\text { wide geographic space } \\
\text { but only certain } \\
\text { communities/ receptors } \\
\text { in that space }\end{array}$ & $\begin{array}{l}\text { Acid rain deposition may cause harm at a number of } \\
\text { localised sites even though the spatial extent of } \\
\text { deposition may be more widespread (e.g. within an } \\
\text { upland region sensitive heathland ecosystems may } \\
\text { be damaged). }\end{array}$ \\
\hline $\begin{array}{l}\text { A4 } \\
\text { Temporal } \\
\text { extent }\end{array}$ & $\begin{array}{l}\text { This describes the } \\
\text { period over which } \\
\text { harm occurs }\end{array}$ & $\begin{array}{l}\text { The impact of a release may be short if a pollutant is } \\
\text { readily degradable but much longer term for non- } \\
\text { degradable (persistent) pollutants. Duration of an } \\
\text { illness will affect the monetary value placed on the } \\
\text { loss of quality of life. } \\
\text { This attribute includes latency so, for example, } \\
\text { damage that becomes evident only after a period of } \\
\text { time (e.g. asbestosis, cancer) would attract a high } \\
\text { rating. }\end{array}$ \\
\hline $\begin{array}{l}\text { A5 } \\
\text { Severity of } \\
\text { effect }\end{array}$ & $\begin{array}{l}\text { Magnitude of damage } \\
\text { to the receptor }\end{array}$ & $\begin{array}{l}\text { Discomfort or irritation are less severe effects than } \\
\text { death from cancer; this is reflected in the value } \\
\text { given in economic terms as well as by the greater } \\
\text { social acceptability of less severe effects of harm. A } \\
\text { catastrophic event would attract a high rating for } \\
\text { this attribute. For example, BSE had catastrophio } \\
\text { consequences on the agricultural economy. }\end{array}$ \\
\hline $\begin{array}{l}\text { A6 } \\
\text { Irreversibility }\end{array}$ & $\begin{array}{l}\text { The extent to which } \\
\text { damage can be } \\
\text { rectified }\end{array}$ & $\begin{array}{l}\text { Harm to the natural environment from flooding is } \\
\text { reversible over time. } \\
\text { Harm is considered irreversible in economic terms } \\
\text { where the costs and difficulties of restoring the } \\
\text { damage are excessive. This attribute is important } \\
\text { when remediation options are being considered; an } \\
\text { activity or event giving rise to substantial harm may } \\
\text { actually be easier to remediate that one causing } \\
\text { more modest impacts. }\end{array}$ \\
\hline $\begin{array}{l}\text { A7 } \\
\text { Uniqueness }\end{array}$ & $\begin{array}{l}\text { Availability of } \\
\text { environmental } \\
\text { resources to substitute } \\
\text { damaged resources }\end{array}$ & $\begin{array}{l}\text { The harm arising from the loss of a site where the } \\
\text { only example of a particular species exists might be } \\
\text { considered greater (in both social and economic } \\
\text { terms) than loss of a site inhabited by more common } \\
\text { species. For example, the loss of an area of salt } \\
\text { marsh might be environmentally more damaging } \\
\text { than loss of an equal area of pine forest. }\end{array}$ \\
\hline
\end{tabular}


Table 2. Examples of Social Response Attributes

\begin{tabular}{|c|c|c|}
\hline $\begin{array}{l}\text { Harm } \\
\text { Attribute }\end{array}$ & Description & Examples \\
\hline $\begin{array}{l}\text { B1 } \\
\text { Dread }\end{array}$ & Fear of "harm" & $\begin{array}{l}\text { There is a greater fear of cancer, relative } \\
\text { to other sudden illnesses. } \\
\text { There is greater fear of death from a plane } \\
\text { crash than from a car accident. } \\
\text { Greater fear of the nuclear industry than } \\
\text { conventional chemical process plant. }\end{array}$ \\
\hline $\begin{array}{l}\text { B2 } \\
\text { Distrust }\end{array}$ & $\begin{array}{l}\text { Lack of trust of the } \\
\text { characterisation of } \\
\text { the impact by the } \\
\text { messenger (e.g. } \\
\text { scientist, } \\
\text { politician). }\end{array}$ & \\
\hline $\begin{array}{l}\text { B3 } \\
\text { Equity }\end{array}$ & $\begin{array}{l}\text { Inequitably } \\
\text { distributed - some } \\
\text { benefit while others } \\
\text { suffer the } \\
\text { consequences }\end{array}$ & $\begin{array}{l}\text { Placing a polluting factory near a deprived } \\
\text { area - losses in economic terms (e.g. value } \\
\text { of the land) may not be as significant } \\
\text { relative to placing it in land considered to } \\
\text { be more value. Greenhouse gas emissions } \\
\text { result in benefits to the present generation } \\
\text { but may result in climate change which } \\
\text { might harm future generations. Long-term } \\
\text { effects in the Ukraine after Chernobyl. }\end{array}$ \\
\hline $\begin{array}{l}\text { B4 } \\
\text { Imposition }\end{array}$ & $\begin{array}{l}\text { Degree of personal } \\
\text { control }\end{array}$ & $\begin{array}{l}\text { There is greater aversion to harm that is } \\
\text { outside our control and externally imposed. } \\
\text { Smoking, rock climbing or knowingly } \\
\text { living in a flood plain. } \\
\text { This factor has been used to adjust economic } \\
\text { valuations of mortality risk reduction from } \\
\text { one context (e.g. road accidents, cigarette } \\
\text { smoking) to another (e.g. pollution hazards). }\end{array}$ \\
\hline $\begin{array}{l}\text { B5 } \\
\text { Familiarity }\end{array}$ & $\begin{array}{l}\text { Degree of } \\
\text { knowledge and } \\
\text { understanding of } \\
\text { the harm }\end{array}$ & $\begin{array}{l}\text { People are more comfortable with risks } \\
\text { with which they are familiar (e.g. drinking } \\
\text { alcohol) relative to novel risks such as the } \\
\text { potential harm from exposure to } \\
\text { genetically modified foods. }\end{array}$ \\
\hline
\end{tabular}

The attributes listed in Tables 1 and 2 were classified as high, medium or low. For clarity they are shown separately within each group but no form of ranking is implied. The B 'how do we feel about it' scores are mostly high reflecting public dread of the nuclear industry, lack of familiarity, distrust, a feeling of imposition and concern about the inequity of inter-generational effects. It should be noted that the results, and particularly the B scores, provide only a snapshot as public 
understanding and perception can change over time. The A scores show greater variability. For example, A3 heterogeneity is low as, although low-level radioactive deposition may be widespread, only localised farming areas may be affected, as in the case of Chernobyl. Similarly, effected ecosystems are not necessarily unique and $A 7$ therefore attracts a low score. In contrast because of the latency of the onset of cancer the A4, temporal extent, score is high as is A6 for irreversibility.

The results of applying the approach to a range of air pollution issues and averaging the A and B scores are shown in Figure 3. The issues vary in terms of their positions relative to each other for both the $A$ and $B$ attributes. Radioactive releases scored most highly in terms of societal concern, followed by stratospheric ozone depletion and climate change resulting from greenhouse gas emissions. The lowest B scores were for nuisance pollutants such as noise and radon, the latter influenced by low scores for imposition and distrust. Consideration of the physical attributes scored greenhouse gases most highly followed by stratospheric ozone depletion and radioactivity. Not surprisingly, the lowest A score was for nuisance pollutants such as noise.

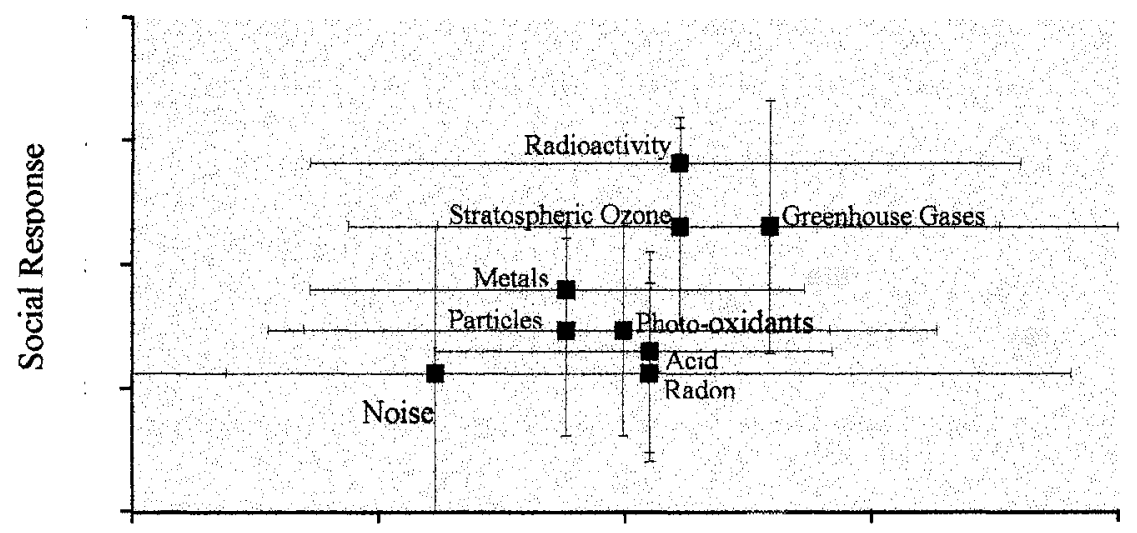

\section{Phvsical Harm}

Figure 3: Social Response - Physical Harm plot for atmospheric pollutants. The error bars represent the standard deviation around the mean score and reflect the variability between all of the attribute scores. The characterisation is for illustrative purposes only, and does not necessarily reflect an Environment Agency position.

\section{Informing regulatory approaches}

Four main regulatory approaches to risk management can be applied across the range of potential environmental harm issues. These approaches are not mutually 


\section{Air Pollution X}

exclusive, and can be broadly characterised in terms of physical attributes, social response and probability

Precautionary Approach. Low to medium probability, uncertain but potentially high and irreversible risks with high latency. Often high social concern.

Firm Enforcement / Strict Liability. High-probability, high-consequence risks. Usually high social concern

Risk Communication and Participatory Regulation. High social concern. Low consequence, and low to high probability.

Environmental Monitoring and Education. Uncertain probability and consequence, but unlikely to be so high as to require firm enforcement. Low to moderate social concern.

Plotting the social response ( $\mathrm{B}$ attribute) scores against the physical (A attribute) scores provides a means of comparing the social versus physical valuation of harm associated with a hazard. Plotting the averages and ranges (as in Figure 3 ) gives an overall characterisation of both the harm and the variability of the A and B attributes. While this is potentially useful it does not in itself take account of the probability of the harm being realised and, in practice, many issues will tend to cluster towards the centre of the plot.

In developing a risk management strategy, Figure 3 indicates that climate change resulting from greenhouse gas emissions may be the highest priority. However, although a lower probability, accidental radioactive releases merit attention because of their high social concern. Considering the position of an issue on the diagram and the individual attribute scores (not shown), can help to inform risk management techniques. For example, in the case of acid deposition management techniques should focus on reducing the coverage, reducing the temporal extent, and improving reversibility. Techniques to reduce coverage include control of output and international co-ordination. Possible techniques to reduce temporal extent include development of alternatives, incentive schemes, and encouraging voluntary commitments to reduction. For accidental radioactive releases, risk management techniques need to aim at reducing concern and discontent, reducing impact, and reducing temporal extent. Appropriate techniques to handle social concerns include education, focusing on risks affecting public health, and stringent liability.

Further work is underway to develop a more comprehensive framework, taking account of probability and uncertainty, in order to assist in mapping available regulatory approaches to risk management.

\section{References}

[1]RCEP, Royal Commission on Environmental Pollution. Twenty-First Report: Setting Environmental Standards, The Stationery Office: London, 1998. 
[2] German Advisory Council on Global Change. World in Transition: Strategies for Managing Global Environmental Risks, 1999.

[3]Duarte-Davidson, R., Pollard, S.J.T., Yearsley, R., Llewllyn, G. \& Steele, J. Considering 'Environmental Harm': Qualitative and Semi-quantitative Treatments for Strategic Risk Assessment. Risk Analysis: Facing the New Millennium, ed. L.H.J. Goossens, Delft University Press: Delft, pp. 231-235, 1999.

[4]Environment Agency. A Strategic Approach to the Consideration of Environmental Harm, Environment Agency: Bristol, 2002.

[5]Environment Agency. Environment 2000 and Beyond, Environment Agency: Bristol, 2000.

\section{Acknowledgements}

Thanks are due to colleagues in the Environment Agency who have developed the approach described, taken part in workshops to apply it to air pollution issues and commented helpfully on this paper. The views expressed are those of the authors alone and not necessarily those of the Environment Agency. 